\title{
Type and Feasibility of Agribusiness of Kub Chicken Household Scale
}

\author{
Setiasih $^{*}$, Ahmad Mualif Abdurrahman, Catur Hermanto and Moh. Saeri \\ Assessment Institute for Agricultural Technology of East Java, Jl. Raya Karangploso Km. 4 Malang, \\ Indonesia
}

\begin{abstract}
The aims of this assessment are to determine the type of KUB chicken agribusiness and feasibility of its business in household scale. The assessment was carried out from November to December 2020 using a survey method. Data were collected by using structured questionnaires to 133 KUB chicken farmers in East Java. Data were analyzed descriptively, using tabulation methods for understanding farming conditions and $\mathrm{R} / \mathrm{C}$ ratio analysis for knowing economic feasibility. The results showed that there were many types of businesses run by KUB chicken farmers in East Java, namely day old chicks (DOC) production 29\%, meat production 29 $\%$, consumption egg production $19 \%$, and others are hatching eggs and pullet productions. Farming population capacity was more than 100 (30.5\%), 50-100 chickens (35.9\%) and less than 50 chickens (33.6\%). The highest business feasibility was in the type of breeding business for DOC production with an $\mathrm{R} / \mathrm{C}$ ratio of 2.12 , and the lowest was in egg production and meat production with $\mathrm{R} / \mathrm{C}$ ratio of 1.16 . It can be concluded that the main type of business that has a high value of business feasibility in the household scale KUB chicken farm in East Java is the nursery to produce DOC.
\end{abstract}

\section{Introduction}

Indonesian Agency of Agricultural Research and Development of Agriculture Ministry has released a strain of the Balitbangtan Superior Native Chicken (KUB), known as KUB-1 Chicken, to fulfill the growing demand of native chicken meat with an intensive maintenance system. This chicken is a pure native chicken as a result of female selection for six generations with a fairly high egg production (160-180 eggs/year), 60\% henday and with broodiness only $10 \%$ of the total population [1-4]. The KUB-1 chicken, a laying type chicken, is expected to provide a solution to the current scarcity of native chicken breeds.

KUB-1 chicken is also used as a meat-producing chicken due to the high market demand. The growth of intensively reared KUB-1 chickens can be harvested at the age of 70 days with body weight around $830.55 \mathrm{~g}$ on male and $691.51 \mathrm{~g}$ on female $[1,5,6]$. Intensive maintenance of native chickens by farmer has increased since 2005 after the outbreak of avian influenza cases $s$ in Indonesia [7,8] agribusiness of KUB-1 chicken is quite attractive to the public by seeing the high demand for KUB day old chick (DOC) that

*Corresponding author : setiasihchaidar@gmail.com 
has not been fulfilled from government-owned breeding units, private breeding companies holding licenses and independent KUB chicken breeders. According to [9], KUB chickens have better prospect and a fairly broad marketing because it is needed at any time and is compatible with the culinary menus of Indonesia. The Price of KUB chickens, both male and female, is relatively higher, when compared to other types of chickens, as well as the price of DOC [10-12].

The development of KUB chicken agribusiness in the community shows that KUB chicken entrepreneurs run a farming with several types of farming based on the purpose of the products produced, namely; a) carcass production (70 days harvest), b) DOC production, c) Pullet production (female and male), d) egg production for consumption and e). the combination of them. According to Suharyon et al.,[13], the feasibility of the KUB chicken farming can be done by analyzing the $\mathrm{R} / \mathrm{C}$ ratio [14]. If the $\mathrm{R} / \mathrm{C}$ value is more than 1 , the farming is profitable and deserves to be continued so that it will become a sustainable farming. The aim of the study was to determine the type and feasibility of the farming system chosen by farmer.

\section{Material and Method}

The study was conducted using a survey method in October - December 2020. The characteristics of the breeder and the type of farming were obtained by interviewing using a questionnaire with the respondents involved as many as 133 KUB chicken farmers in the East Java Province. The observed variables were Individual characteristic of farmers, type of farming based on product goals, population and rearing system, and production cost. Production cost data was obtained by conducting in-depth interviews about technical and economical with 10 farmers who are members of the Berkah Alam Makmur Cooperative, East Java.

Economic feasibility is analyzed using the $\mathrm{R} / \mathrm{C}$ ratio which is a comparison between total revenues and costs. This analysis was conducted to determine the economic value and efficiency level of a business, in this case the KUB chicken business. The observed variables include Cost Value, Revenue Value, Profit Value and R/C Ratio Value [15] [16]. Total Cost (TC) is the total cost consisting of total variable costs (TVC) and total fixed costs (TFC). The costs used in this study include the overall value of financial inputs that are actually spent to finance the KUB Chicken business production process, with the equation:

$$
T C=T F C+T V C
$$

Total Revenue (TR) is the total money received from successfully sold products, or the multiplication of the number of products produced (Q) with the selling price per unit product $(\mathrm{P})$, with the following equation:

$$
T R=P x Q
$$

The Equation of R/C Ratio:

$$
R / C=T R / T C
$$

The criteria used to assess the R/C Ratio are as follows:

a. $\mathrm{R} / \mathrm{C}$ Ratio $>1$ means the business is profitable.

b. $\mathrm{R} / \mathrm{C}$ Ratio $<1$ means business is unprofitable

c. $\mathrm{R} / \mathrm{C}$ Ratio $=1$ means a break-even point $(\mathrm{BEP})$. 


\section{Results and Discussions}

\subsection{Farmer Characteristic}

In 2020, there have been 133 independent farmers in East Java. The majority of farmers are male $(95.3 \%)$ and young age $19-39$ years $(74.8 \%)$. This shows that millennial have easier access than older farmers to access information about KUB Chicken that available via the internet or social media. Another advantage of the young age of farmers are the ease and speed of adopting technology $[17,18,19]$.

Table 1. Characteristics of East Java KUB Chicken Farmers ( $\mathrm{n}=133$ people)

\begin{tabular}{|c|l|c|c|c|c|}
\hline No. & Characteristic & Percentage & Number & Characteristic & Percentage \\
\hline 1 & Sex & & 4 & Education & \\
\hline & Female & 4.7 & & Junior High School & 10.1 \\
\hline & Male & 95.3 & & Senior High School & 51.4 \\
\hline 2 & Age & & & Bachelor & 38.5 \\
\hline & $19-39$ & 74.8 & & & \\
\hline & $40-56$ & 22.6 & 5 & Main income & \\
\hline & More than 56 & 2.6 & & Farming & 16.54 \\
\hline 3 & Experience (year) & & & Livestock & 27.07 \\
\hline & $0-1$ & 56.9 & & Merchant & 24.06 \\
\hline & $>1-3$ & 17.7 & & Employee & 20.30 \\
\hline & $<3$ & 25.4 & & others & 12.03 \\
\hline
\end{tabular}

More than half of KUB chicken farmers in East Java (56.9\%) are beginner with $0-1$ years of experience raising chickens and other poultry. This indicates that the KUB chicken business is a business opportunity that can be carried out during the COVID-19 pandemic which began to feel its impact in March 2020. About 25.4\% are farmers with experience less than 3 years. The main motivation for choosing KUB-1 chicken business is the potential advantages of KUB chicken.

\subsection{KUB Chicken Farming Typology}

KUB-1 chickens can be used as dual-purpose livestock that can produce meat and eggs, giving rise to many types of businesses, namely; 1) Production of carcass and meat, 2). Production of consumption eggs, 3) Production of hatching eggs, 4). Production of pullets, 5). DOC production, 6). Hatching, and 6). Post-harvest and marketing. All types of KUB chicken businesses in East Java with a percentage as shown in Figure 1.

The type of farming that is mostly chosen by farmers is carcass production (29\%) and DOC $(29 \%)$. Carcass production was chosen because this business is the easiest to do and the capital turnover is fast. Breeding for the production of DOC was chosen because there are not many business actors, while the demand for KUB chicken DOC is quite high. some farmers have also started off-farm farming in the form of post-harvest processing.

The population in the household-scale KUB-1 chicken farming business in East Java is mostly more than $50(34 \%)$ and 51-100 (35.9\%), and 101-500 (21\%). More than $70 \%$ of farmers only have laying hen as egg producers of less than 50. Most of the farmers raise their chickens with an intensive system and some with a semi-intensive system. Intensive systems make it easier to handle and control disease and can increase the production of native chicken eggs. 


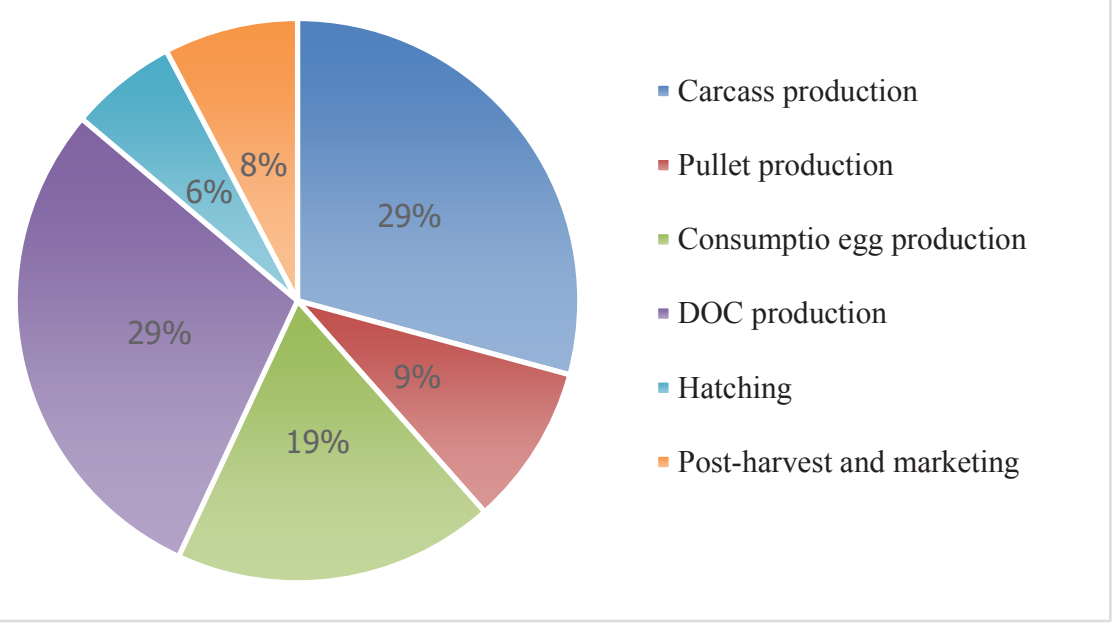

Fig. 1. Type of farming and population of KUB-1 chicken

\subsection{Farming Feasibility}

Economic analysis of various types of KUB chicken farming carried out by farmers with a rearing capacity of $200 \mathrm{DOC}$ is presented in Table 2. It can be seen that KUB chicken farming with the objectives of carcass production, pullet production, hatching egg production and DOC production is economically feasible because all of the $\mathrm{R} / \mathrm{C}$ values are more than 1 .

The most profitable type of farming is breeding for DOC production with R/C 2,12. Then following by pullet production farming 1,23, egg production consumption 1,17 and carcass production 1,16 . An $\mathrm{R} / \mathrm{C}$ value of more than 1 indicates that the farmer still has a profit after spending all production costs. The highest cost of all types of chicken farming is the cost of feed. Therefore, the rise and fall of feed prices will greatly affect the income that will be received by farmers. The skills of breeders in feed management (ration formulation) to produce cheap and quality feed so that they do not depend on manufacturer's feed are the key to success and sustainability. Subagiyo et al.,[20] reported the results of a financial analysis of using local feed economically to provide a profit of IDR 2,360,700 with an R/C efficiency level of 1.27, the break-even point is IDR 21,187.

Breeding farming to produce DOC is more profitable than producing consumption eggs, even though the length of one cycle period required is the same. The price of DOC (IDR. $7,500,-)$ is much higher than that of consumption eggs (IDR 2,500,-). This is also influenced by the level of egg hatchability. According to Wantasen et al., [21] the acceptance of the chicken breeding business is influenced by the hatching rate, the number of productive chickens, production costs and the number of eggs hatched, [21-23].

Isbandi dan Agustina[24] reported that KUB chicken breeding farming in Jago Village, Praya District, Central Lombok Regency, West Nusa Tenggara is feasible because it has an $\mathrm{R} / \mathrm{C}$ ratio of 2.76 in one production cycle. Breeding farms producing DOC per production cycle can be profitable with a ratio of $\mathrm{R} / \mathrm{C}$ more than 2 in one year $[25,26,27,28]$.

The type of KUB chicken farming for carcass production resulted in an $\mathrm{R} / \mathrm{C}$ value of 1.16. This is not much different from the research results of Rusdiana and Praharani, reported that the price of 8-week-old KUB native chickens obtained an R/C ratio of 1.3 [9]. Asnidar reported that the minimum scale of KUB chicken farming for carcass production was 200 heads each period for 12 weeks, with an R/C ratio of 1.14 [29]. 
Tabel 2. Economic analysis of various types of KUB chicken farming

\begin{tabular}{|c|c|c|c|c|c|c|c|c|c|c|c|c|}
\hline & \multicolumn{3}{|c|}{ Carcass Production } & \multicolumn{3}{|c|}{ Pullet Production } & \multicolumn{3}{|c|}{ Egg Consumption Production } & \multicolumn{3}{|c|}{ DOC Production } \\
\hline Cost & volume & Unit & Value (IDR) & volume & Unit & Value (IDR) & volume & Unit & Value (IDR) & Volume & Unit & Value (IDR) \\
\hline \multicolumn{13}{|l|}{ Fix Cost } \\
\hline Depreciation of cage & 2.5 & Month & 162,500 & 4 & Month & 428,000 & 18 & Month & $1,926,000$ & 18 & Month & $1,926,000$ \\
\hline Depreciation of equipment & 2.5 & Month & 37,500 & 4 & Month & 100,000 & 18 & Month & 630,000 & 18 & Month & $1,350,000$ \\
\hline \multicolumn{13}{|l|}{ Variable Cost } \\
\hline Day Old Chick & 200 & Head & $1,500,000$ & 200 & Head & $1,500,000$ & 200 & Head & $1,500,000$ & 200 & Head & $1,500,000$ \\
\hline Starter period feed & 70 & $\mathrm{Kg}$ & 490,000 & 70 & $\mathrm{Kg}$ & 490,000 & 70 & $\mathrm{Kg}$ & 490,000 & 70 & $\mathrm{Kg}$ & 490,000 \\
\hline Grower Feed & 400 & $\mathrm{Kg}$ & $2,240,000$ & 1,000 & $\mathrm{Kg}$ & $5,600,000$ & 1,000 & $\mathrm{Kg}$ & $5,600,000$ & 1,000 & $\mathrm{Kg}$ & $5,600,000$ \\
\hline Layer Feed & 0 & $\mathrm{Kg}$ & - & 0 & $\mathrm{Kg}$ & - & 3,900 & $\mathrm{Kg}$ & $18,330,000$ & 4,290 & $\mathrm{Kg}$ & $20,163,000$ \\
\hline Vaccine and drug & 1 & Pack & 52,000 & 1 & Pack & 362,000 & 1 & Pack & $2,987,000$ & 1 & Pack & $2,987,000$ \\
\hline Vitamin & 0.1 & $\mathrm{Kg}$ & 9,800 & 0,5 & $\mathrm{Kg}$ & 49,000 & 3 & $\mathrm{Kg}$ & 294,000 & 3 & $\mathrm{Kg}$ & 294,000 \\
\hline Disinfectant & 0.1 & litter & 7,500 & 0,5 & litter & 37,500 & 3 & litter & 225,000 & 3 & litter & 225,000 \\
\hline Litter & 3 & bag & 24,000 & 9 & bag & 72,000 & 45 & bag & 360,000 & 45 & bag & 360,000 \\
\hline Electricity and water & 68 & kwh & 88,400 & 124 & kwh & 161,200 & 844 & kwh & $1,097,200$ & 844 & kwh & $1,097,200$ \\
\hline Labor & 2.5 & Month & 850,000 & 4 & Month & $1,360,000$ & 18 & Month & $6,120,000$ & 18 & Month & $12,600,000$ \\
\hline Total Cost & & & $5,461,700$ & & & $10,159,700$ & & & $39,559,200$ & & & $48,592,200$ \\
\hline \multicolumn{13}{|l|}{ Revenue } \\
\hline Slaughtered & 195 & Head & $6,337,500$ & 72 & Head & $2,340,000$ & 70 & Head & $2,275,000$ & 70 & Head & $2,275,000$ \\
\hline Male and female pullet & 0 & Head & 0 & 120 & Head & $10,200,000$ & 0 & Head & 0 & 0 & Head & 0 \\
\hline Consumpsion eggs & 0 & item & 0 & 0 & item & 0 & 16,146 & Item & $40,365,000$ & 12,917 & Item & $96,876,000$ \\
\hline DOC & 0 & Head & 0 & 0 & Head & 0 & 104 & Head & $3,640,000$ & 104 & Head & $3,640,000$ \\
\hline Total Revenue & & & $6,337,500$ & & & $12,540,000$ & & & $46,280,000$ & & & $102,791,000$ \\
\hline Profit & & & 875,800 & & & $2,380,300$ & & & $6,720,800$ & & & $54,198,800$ \\
\hline $\mathrm{R} / \mathrm{C}$ & & & 1.16 & & & 1.23 & & & 1.17 & & & 2.12 \\
\hline Production Cycle Periode & \multicolumn{3}{|c|}{2.5 months } & \multicolumn{3}{|c|}{4 months } & \multicolumn{3}{|c|}{18 months } & \multicolumn{3}{|c|}{18 months } \\
\hline
\end{tabular}




\section{Conclusion and Suggestion}

\subsection{Conclusion}

KUB chicken farming that has developed a lot is the type of farming that has the objectives of carcass production, DOC production, pullet production and egg production for consumption. All types of farming are economically feasible to do with different $\mathrm{R} / \mathrm{C}$ values. Breeding farming to produce DOC is the most profitable with an $\mathrm{R} / \mathrm{C}$ value of 2.12 for one production cycle (18 months).

\subsection{Suggestions}

It is recommended that a network be formed between groups that produce different KUB chicken farm products, support each other, so that they become a strong and sustainable KUB Chicken production institution.

\section{References}

1. T. Sartika, Desmayati, S. Iskandar, H. Resnawati, A. R. Setioko, Sumanto, A. P. Sinurat, Isbandi, B. Tiesnamurti, and E. Romjali, Ayam KUB-1 (IAARD Press., Jakarta, 2013).

2. C. Hidayat, S. Iskandar, T. Sartika, and T. Wardhani, J. Ilmu Ternak Dan Vet. 21, (2017).

3. L. O. Pius, P. Strausz, and S. Kusza, Biology (Basel). 10, (2021).

4. T. Sartika, S. Sulandari, and M. S. A. Zein, BMC Proc. 5, (2011).

5. S. Burgos, P. T. Hong Hanh, D. Roland-Holst, and S. A. Burgos, Int. J. Poult. Sci. 6, (2007).

6. C. Hidayat and S. Iskandar, J. Ilmu Ternak Dan Vet. 22, (2018).

7. T. Sartika, in Pros. Work. Nas. Unggas Lokal (2012), pp. 15-23.

8. S. Iskandar, PETUNJUK TEKNIS PRODUKSI AYAM LOKAL PEDAGING UNGGUL: Program Perbibitan Tahun 2017 (Pusat Penelitian dan Pengembangan Peternakan, Bogor, 2017).

9. S. Rusdiana and L. Praharani, J. Sain Peternak. Indones. 14, (2019).

10. A. Y. Fadwiwati, Surya, and Rosdiana, in IOP Conf. Ser. Earth Environ. Sci. (2021).

11. S. Tirajoh, G. P. Dominanto, Usman, A. Soplanit, and B. Bakrie, in IOP Conf. Ser. Earth Environ. Sci. (2021).

12. S. J. Hiemstra and J. Ten Napel, Study of the Impact of Genetic Selection on the Welfare of Chicken Bred and Kept for Meat Production (2013).

13. Suharyon, Zubir, and E. Susilawati, J. Ilm. Ilmu Terap. Univ. Jambi 4, 24 (2020).

14. S. Munawaroh, A. A. Rouf, D. Rohmadi, S. Anas, Rosdiana, and A. Nur, in IOP Conf. Ser. Earth Environ. Sci. (2021).

15. Kasmir and Jakfar, Studi Kelayakan Bisnis (Edisi Revisi) (Kencana, Jakarta, 2013).

16. S. Noonari, M. I. N. Memon, M. A. Kolachi, A. A. Chandio, S. A. Wagan, A. A. Sethar, G. Y. Kalwar, M. A. Bhatti, A. S. Korejo, and G. M. Panhwar, J. Econ. Sustain. Dev. 6, 118 (2015). 
17. W. Lestari, S. Hadi, and N. Idris, J. Ilm. Ilmu-Ilmu Peternak. Univ. Jambi XII, (2009).

18. H. Li, D. Huang, Q. Ma, W. Qi, and H. Li, Sustain. 12, (2020).

19. M. Mwangi and S. Kariuki, ISSN 6, (2015).

20. Subagiyo, S. B, and H. H, in Pros. Semin. Nas. Teknol. Peternak. Dan Vet. (Indonesian Center for Animal Research and Development (ICARD), Bogor, 2015), pp. 570-575.

21. E. Wantasen, F. H. Elly, and N. M. Santa, J. Indones. Trop. Anim. Agric. 39, (2014).

22. R. Afandi, B. Hartono, and I. Djunaidi, Trop. Anim. Sci. J. 43, (2020).

23. M. Y. Birhanu, T. Alemayehu, J. E. Bruno, F. G. Kebede, E. B. Sonaiya, E. H. Goromela, O. Bamidele, and T. Dessie, Sustain. 13, (2021).

24. Isbandi and A. N, in Pros. Semin. Nas. Teknol. Peternak. Dan Vet. (Indonesian Center for Animal Research and Development (ICARD), Bogor, 2015), pp. 557-563.

25. S. Suryana, Wartazoa 27, 45 (2017).

26. A. N. Respati, A. Hakim, and A. H. A. Kusuma, Bantara J. Anim. Sci. 2, (2020).

27. S. Nurlaelah, A. Asnawi, and R. Rusni, in IOP Conf. Ser. Earth Environ. Sci. (2021).

28. Sunarno, E. S. Rahayu, and S. H. Purnomo, Pros. Semin. Nas. Int. 1, (2016).

29. Asnidar, Rahayu HSP, Wardi, and Takdir M, in (2019). 